\title{
COSTS CAUSED BY THE IMPLEMENTATION OF THE NEW LAW IMPOSED ON POLISH SKI RESORTS
}

\author{
JADWIGA BERBEKA, ${ }^{1}$ KRZYSZTOF BERBEKA $^{2}$ \\ ${ }^{1}$ Cracow University of Economics \\ Faculty of Management, Department of Tourism \\ e-mail: jadwiga.berbeka@uek.krakow.pl \\ ${ }^{2}$ Jagiellonian University \\ Institute of Economics, Finance and Management \\ e-mail: krzysztof.berbeka@uj.edu.pl
}

\section{JEL CODES}

KEYWORDS

ABSTRACT
D23, K32, L51

safety standards, cost of new law implementation, safety in ski centers

Law regulations are external determinants of any entity functioning on the market, so their changes have direct economic consequences for each enterprise or institution. In the paper an attempt was made to estimate results of implementation of the Act of 18 August 2011 on Safety and Rescue in the Mountains and the Organized Ski Areas for Polish ski resorts. The methodology suggested in the paper seems to be of a universal character, it offers the calculation of additional costs resulting from legal regulation per capacity of ski resort ( $€$ per year/1,000 persons capacity). So it may be a tool to analyze the consequences for the competitiveness of any European ski resort. The results for Polish ski resorts reveal that the new regulations imposed by the Act of 18 August 2011 have generated additional costs for a resort of approximately $1,000 € /$ year/1,000 persons capacity.

\section{Introduction}

The increase of people's welfare causes higher expectations concerning the level of security and safety. Such expectations concern also recreation activities, including Alpine skiing. Therefore year by year the problem of establishing the optimum level of safety for skiers seems to be more and more important and difficult. An answer to the question "how safe is safe enough?" seems to be challenging for quantitative analysis. The main aim of the paper is an attempt to make the 
analytical description of associated costs and benefits related to improving the security level in Alpine ski resorts. The case study which illustrates proposed methodology is based on Polish ski centres, however a serious effort was made to prepare a universal methodology, applicable in European conditions.

\section{Theoretical background}

On the one hand, almost all regulations cause some costs of meeting legal requirements. While on the other - the expected effects of implementation of such requirements are treated as benefits. Relevant costs and benefits in decision-making process are marginal costs and marginal benefits. The break point where marginal costs of meeting the legal regulation are equal to the marginal benefits indicates the best choice maximising social welfare. Such a balance that one relocation can make anyone better off without making at least one other person (an entity) worse off than a Pareto optimum is claimed to exist (Pearce, 1992). The discussed case is related to the optimal level of safety in Alpine ski centres. Therefore the curve of marginal costs (MC) consists of technical and organisational undertakings aimed at improvement of safety on the slopes. The curve of marginal benefits (MB) consists of the benefits related to avoided incidents on the slopes, also the higher demand for practising ski in more safe ski-centres should be taken into consideration. For purpose of quantitative approach the monetary valuation of all effects is necessary. Using quite an optimistic assumption that it is possible to get a proxy of the main sources of costs and benefits - such a valuation of the optimal level of safety is presented on Figure 1.

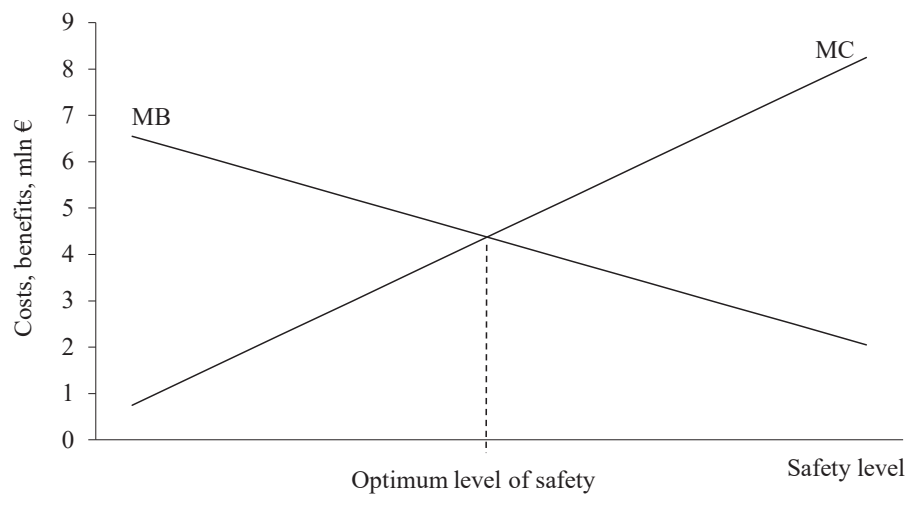

Figure 1. Economic definition of optimum safety level

Source: own study. 


\section{Polish ski resorts and law regulations concerning their operations}

Polish ski centers due to less favorable conditions than in Alpine countries are rather small, more than a half of them are served by only one ski lift, which means they are not considered as ski resort in the Alpine standard (usually the criterion is 4 ski lifts - see Vanat, 2015). There are 72 ski resorts with minimum one chair lift, around 160 ski resorts in general and approximately 300 ski areas with at least one ski lift (Berbeka, 2014).

The majority of ski resorts are located at the altitude lower than $1000 \mathrm{~m}$ above sea level; only 1 has the upper station higher than 1,500 $\mathrm{m}$ above sea level. Many resorts are located in proximity to agglomerations: they usually work 7 days a week, 12-14 h/day. This means all of them have artificial lighting on slopes.

The role of ski resorts in the regional economy is crucial (Berbeka 2018). Direct, indirect and induced effects of skiers spending are the main factors of local development (Della Lucia, 2015). That is why the conditions of their operation, including legal determinants, have so significant meaning and should be comprehensively analyzed.

The new law regulation was imposed in 2011, it was the Act of 18 August 2011 on Safety and Rescue in the Mountains and the Organized Ski Areas (Wolski, 2015). Certain obligations imposed by the Act may cause additional financial burden compared to the previous regulations. The following should be mentioned:

1. Ensuring a minimum area of ski slopes necessary per one skier, depending on slope difficulty and a minimum light intensity on slopes with artificial lighting.

2. Organization of rescue services in organized ski areas: operator's obligation is to organize and finance rescue or contract Mountain Rescue Service to do it for the resort.

3. Securing ski areas: marking ski slopes, marking specific obstacles and dangerous places although this obligation has already existed.

It should be mentioned however that the enforcement of above obligations is not strict.

\section{Modelling approach}

The problem of identification of the costs caused by implementation of the safety regulation is quite challenging due to the lack of ceteris paribus conditions. The Alpine skiing business is very dynamic and the market is quite far from ideal due to a different level of internalisation of the external costs, and high travel costs - especially in case of weekend and short break trips. Also the term "costs of meeting legal requirements" needs some simplifications and detail description. First of all the analysis is possible only in relation to the implementation of the new regulation (usually more strict than the previous one). It's impossible to analyse the historical development of all regulations and associated costs of implementation. Therefore we have to do with some increase of the safety due to an implementation of selected technical or organisational solutions and some effects expressed by a number of accidents. Such an assumption (focusing on the increase of the costs only) is still not well defined due to different understanding/meanings of the term "cost". Following types of costs where included in the analysis: 
1. One time investment outlays (for example caused by widening slopes and replacement of lighting of slopes).

2. Continuous (or seasonal) expenditures - like artificial snowing of additional part of slopes, annual fee for deforestation, costs of additional ground renting for slopes.

3. Stranded Costs - in case of ski resort closing, because of unprofitability of running under new regulations.

4. Penalties for not meeting the requirements.

5. Recourses from insurance companies (in case of partial fulfilment of all legal requirements by ski-centre operator).

Above specified streams of costs have two different formats: $€$ or $€ / y$. Such discrepancies require the application of methods enabling comparison and aggregation of all incremental costs. Because the benefits have an annual character (changes in annual number of incidents) - all costs should be recalculated into annualized cost which express annual burdens caused by implementation of necessary technical and organisational undertakings. After such a recalculation all streams have the same format and such categories have the additive character.

The annualised costs are described by the following equation:

$$
A C=I \times \frac{(1+r)^{n}}{\left((1+r)^{n}-1\right)}+O
$$

where:

$A C$ - annualised costs,

$I \quad$ - investment outlays,

$O$ - total annual operating and maintenance costs,

$r$ - the discount rate,

$t$ - lifetime of the fixed assets.

Equation 1 is valid only when operating costs do not change over time (in real prices). The annualised costs calculated using equation 1 are still not comparable between ski-resorts because of high differentiation of a size of such entities. The most common unit describing size of ski resorts is (hourly) lifts capacity. Therefore a comparable unit of additional costs caused by the implementation of new safety regulation was calculated as:

$$
A A C=\frac{\sum A C}{L C}
$$

where:

$A C$ - annualised costs of meeting the additional requirements,

$L C$ - lift capacity of 1,000 persons/h.

The benefits of improvement of the safety level consist of two main streams: changes of the number of accidents on the slopes and higher preferences of skiers in their decision-making process 
of choosing a ski resort. Quantification of such processes requires some simplifications. Skipping some difficulties with data collection (described in the next chapter) - the winter seasons are not identical year by year therefore a simple comparison of the total number of accidents does not reflect changes in safety level. The number of the days in operation, different number of guest, different distribution of the number of clients has the influence on the number of accidents. Specified factors require special attempt aimed at standardisation of such data for creditable comparison. The simple method is based on calculation of number of accidents per standardised length of the season.

where:

$$
A_{s t}=A_{r} \frac{100}{D r}
$$

$A_{s t}-$ standardised number of accidents,

$A_{r}$ - real number of accidents,

$D r$ - real number of days in operation per ski season.

The methods aimed at the identification of the skier's preferences related to the safety level require questionnaire surveys or interviews. The results can reveal what percentage of respondents take the safety on slopes of the resort as the criterion in choosing a resort or what is the value of safety for a skier (with the use of Likert scale).

The possibility of adding two streams of benefits exists only when there are the units. In case of such huge differentiation of the factors - only the monetary valuation of both streams seems to be applicable. This quite complicated aspect is not developed in this paper because until now the existing results of identification of consumer preferences on the slopes indicate marginal importance of safety level. In the sample of 1978 skiers only less than $1 \%(16$ persons $=0.4 \%)$ pointed to safety (Krzesiwo, 2014). In such a case only the number of accidents seems significant and there is no need for application of monetary valuation.

Finally on the side of the costs there is an indicator expressed in $€ / 1,000$ capacity/year and the benefits are represented by changes in number of accidents. In such a situation a simple comparison of the economic efficiency is possible but different units make the reference to the optimum in V. Pareto sense impossible.

\section{Data Collection}

The first step was an analysis of secondary sources: reports of the Ministry of Interior and Supreme Audit Office concerning safety in ski resorts; opinions of the ski sector representatives (Associations) on the Act, records on the discussion between Parliamentary Committees of Tourism and results of questionnaire survey for skiers conducted in 2013 on the sample of 1978 skiers in Polish ski resorts (Krzesiwo, 2014). 
The main primary source of data was the results of the questionnaire survey conducted with ski resorts operators. The link to the questionnaire was sent to 81 resorts associated in the Polish Association of Ski and Tourist Resorts.

Representatives of 15 ski resorts filled in the questionnaire, what gives the rate of return (ROR) at the level of 19\%; participating ski resorts have 49 ski lifts (not including conveyor belt/ magic carpets), the sum capacity of all lifts in these resorts is 56 thousand persons $/ \mathrm{h}$. It is approximately $10 \%$ of the total capacity in Poland. It should be stressed that there is an overrepresentation of "large" ski resorts ( "large" by Polish standards).

Additionally, in-depth interviews were conducted with seven managers/owners of Polish ski resorts. In-depth interviews were also conducted with three Mountains Rescue Service members and two managers of insurance companies.

\section{Modelling}

The specificity of all categories of costs is presented in Figure 2. Our calculations concern costs imposed by the new regulation ("New Act" on Figure 2).

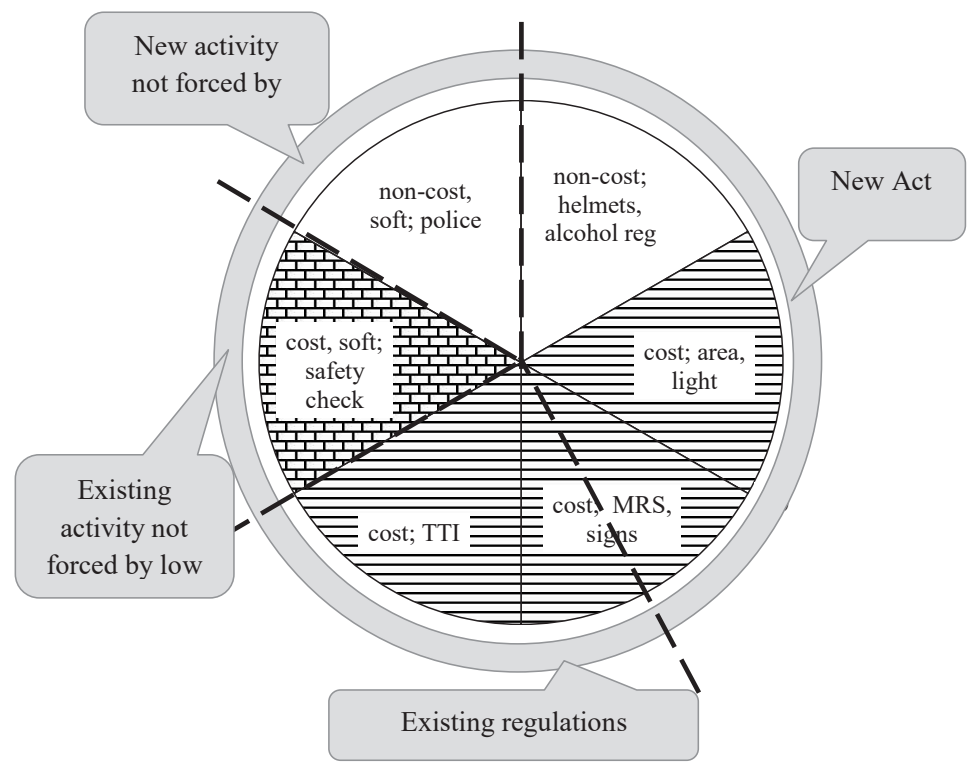

Figure 2. Structure/division of the costs related to the safety on ski resorts

Source: own study.

Application of the methodology described in paragraph 4 and data obtained in questionnaire survey give the results summarised in tables 1 and 2 . 
Tahle 1. Structure of incremental costs reported by Polish ski resorts (\%)

\begin{tabular}{lcc}
\hline \multicolumn{1}{c}{$€ /$ year/1,000 persons capacity } & Percentage of resorts & Percentage of resorts by capacity \\
\hline Resorts reporting costs of meeting the regulations & 57 & 79.0 \\
Cost of slopes widening & 14 & 10.0 \\
Cost of additional artificial snowing & 7 & 7.0 \\
Cost of lighting (improving the parameters) & 29 & 39.0 \\
Other costs & 50 & 75.9 \\
\hline
\end{tabular}

Source: own study.

Table 2. Value of incremental costs of meeting the new safety regulation in Polish ski resorts

\begin{tabular}{lcc}
\hline \multicolumn{1}{c}{$€ /$ year/1,000 persons capacity } & Average in the sample & Average for all resorts \\
\hline Cost of slopes widening & 481.5 & 49.1 \\
Cost of additional artificial snowing & 4843.6 & 343.0 \\
Cost of lighting & 699.2 & 271.3 \\
Other costs & 430.7 & 327.0 \\
Max & 6455.0 & - \\
\hline Total & & 990.7 \\
\hline
\end{tabular}

Source: own study.

The most important figure from the above two tables is the total annualised costs of meeting of the new safety requirements per 1,000-person capacity of the ski resort. The approximate value of $1,000 €$ gives one the proxy of annual financial burden imposed by the new regulation.

\section{Discussion}

The estimation of hypothetical benefits understood as changes in the amount of ski accidents was unsuccessful. The main reason was the insufficient statistic of ski accidents provided by ski-operators. In fact ski resorts have a statistic reporting duty but due to a lack of enforcement regulations only the ski-centres that contracted the rescue services from Mountain Recue Service (GOPR and TOPR in Polish) meet such requirements. Since the number of ski centres with such contracts has been changing over the last decade, the total amount of ski accidents is not credible. Such statistics are available (see Figure 3). However, during the period 2010-2014 the sample of ski centres providing comprehensive data has dropped from 128 to 57. From 2015 data were not published at all.

Recalculation of the above data into units of average number of accidents per one ski centre is also not very credible due to big discrepancies of the size of single entities (see Figure 4). The calculation for 2015-2017 is impossible because the Ministry of Interior has skipped necessary data in the consecutive Reports on the safety level. 


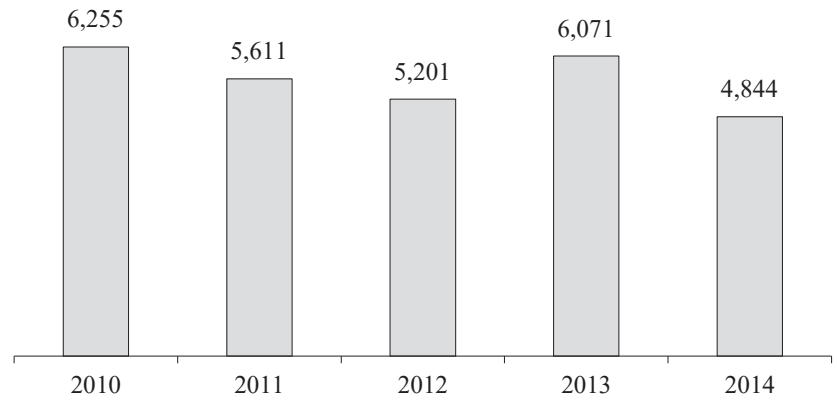

Figure 3. Number of rescue actions organised by Mountain Rescue Service members

Source: The Ministry of Interior (2015).

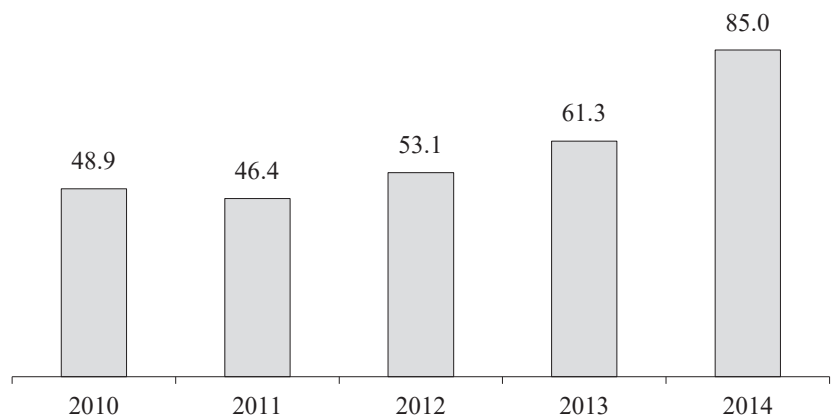

Figure 4. Number of rescue actions organised by Mountain Rescue Service per 1 (reporting) ski resort Source: own calculations on the basis of the Ministry of Interior (2015)

Such a rough estimation is also incorrect. The increase depicted in the above picture is impossible. Therefore much more detailed standardisation described in the methodological chapter is necessary.

\section{Conclusions}

1. The concept of a synthetic indicator of additional costs caused by new law seems to fulfill the requirements of dynamic and international comparison.

2. Number of accidents is a result of many factors: number of days in the season, opening hours per day, number of skiers on slopes. The data referring to the number of skiers and their daily distribution are critical information for a resort and resorts do not want to reveal it. Hence the possibilities of normalization of data are limited. Therefore the impact of new safety regulations is hard to quantify.

3. As a result quite a good proxy of costs is not associated with benefits (avoided accidents). 
4. Benefits are difficult to quantify so the main factor are the costs. It means that national regulations influence the competitiveness of ski resorts on the European market.

\section{Referencencs}

Act of 18 August 2011 on Safety and Rescue in the Mountains and the Organized Ski Areas for Polish ski resorts. Journal of Laws of 2011, No. 208, item 1241.

Berbeka, J. (2014). Impact of Polish ski resort for national Economy. Presentation at VI Conference of Polish Ski and Tourism Resorts 2-4.06.2014. Białka Tatrzańska, Poland.

Berbeka, J. (2018). Rozwój regionów dzięki podnoszeniu atrakcyjności produktu narciarskiego - rola organizacji Polskie Stacje Narciarskie i Turystyczne. Ekonomiczne Problemy Turystyki, 1 (41), 67-74.

Della Lucia, M. (2015). The economic impact of tourism. Winter tourism and the ski industry. Working paper of the international workshop "Safety And Liability Rules In European Ski Areas". Trento.

Krzesiwo, K. (2014). Rozwój i funkcjonowanie stacji narciarskich w polskich Karpatach. Kraków: Uniwersytet Jagielloński.

Pearce, D.W. (1992). The MIT Dictionary of Modern Economics. The MIT Press Cambridge.

The Ministry of Interior (2015). Raport o stanie bezpieczeństwa w Polsce w 2014 roku. Chap. 17.

Vanat, L. (2015). International Report on Snow \& Mountain Tourism-Overview of the key industry figures for ski resorts. Geneve.

Wolski, D. (2015). Polish and Italian law on ski area services - short comparative study. Working paper of the international workshop "Safety And Liability Rules In European Ski Areas". Trento.

\section{KOSZTY SPOWODOWANE WDROŻENIEM NOWYCH REGULACJI DOTYCZACCYCH BEZPIECZEN̂STWA W POLSKICH OŜRODKACH NARCIARSKICH}

SŁOWA KLUCZOWE

STRESZCZENIE standardy bezpieczeństwa, koszty wdrożenia nowego prawa, bezpieczeństwo

w ośrodkach narciarskich

Regulacje prawne wpływają na funkcjonowanie przedsiębiorstwa na rynkach, zatem zmiany tych regulacji mają bezpośredni wpływ na przedsiębiorstwa i instytucje. W pracy podjęto próbę oszacowania ekonomicznego wpływu ustawy z dnia 18 sierpnia $2011 \mathrm{r}$. o bezpieczeństwie i ratownictwie w górach i na zorganizowanych terenach narciarskich wraz z towarzyszącymi jej rozporządzeniami. Zaproponowana metodyka jest możliwa do zastosowania w innych (niż Polska) obszarach. Wskaźnik wzrostu kosztów wyrażony został w $€$ rocznie /1000 osób przepustowości godzinowej ośrodka narciarskiego. Może zatem być narzędziem do analizy porównawczej zmian konkurencyjności ośrodków narciarskich w Europie. Obliczenia wykonane dla badanych ośrodków w Polsce pozwoliły oszacować wzrost kosztów na około $1000 €$ rocznie/1000 osób przepustowości godzinowej ośrodka. 